\title{
Language Identities of Multilingual College English Learners in Indonesia
}

\author{
Emi Nursanti a * (D), Erna Andriyanti a \\ ${ }^{a}$ English Education Department, Universitas Negeri Yogyakarta, Jalan Colombo No. 1, Yogyakarta 55281, Indonesia
}

Received 16 November 2020 | Received in revised form 28 March 2021 | Accepted 29 March 2021

\begin{abstract}
APA Citation:
Nursanti, E. \& Andriyanti, E. (2021). Language identities of multilingual college English learners in Indonesia. Eurasian Journal of Applied Linguistics, 7(1), 316-337.
\end{abstract}

Doi: $10.32601 /$ ejal.911403

\begin{abstract}
College learners with their youthfulness are in a crucial phase of transition, which is often associated with a search of identity. Since language is a fluid identity marker, an investigation of language use to represent identity is challenging, especially when the speakers are multilingual. This article explores the linguistic identities of English college learners in Indonesia and offers an approach of English instruction in its tertiary education context which can accommodate their language identity representation. Through observation, a survey of 173 students of the English Literature Study Program, and in-depth interview with 13 representatives selected by purposive convenience sampling technique, this study found that other than identities related to their language inheritance, their closeness to English as their major of study and to digital media bring out other forms of identity as English Department students, youth, and millennial generation. However, this variety confirms monocultural rather than multicultural identity since they are deeply rooted in their local culture. Using the lingua franca approach, this work proposes a local-oriented English instruction to facilitate them to promote their local culture to international audiences.
\end{abstract}

(C) 2021 EJAL \& the Authors. Published by Eurasian Journal of Applied Linguistics (EJAL). This is an open-access article distributed under the terms and conditions of the Creative Commons Attribution license (CC BY-NC-ND) (http://creativecommons.org/licenses/by-nc-nd/4.0/).

Keywords: Multilingualism; language identity; youth; millennials; local-oriented English

\section{Introduction}

The hegemony of English in various countries often raises the issue of tension between the impact of the language as a global communication tool and the value of local and national languages much associated with the identities of their speakers (Joseph, 2004). There has been a growing interest in the impact of the existence of this language in multilingual and multicultural societies as in the studies conducted by Bhat (2017), Bristowe, Oostendorp \& Anthonissen (2014), Lie (2017), and Zentz (2012). However, in the Indonesian context, "the second most linguistically diverse nation in

\footnotetext{
* Corresponding author. Tel.: +62-856-4390-1602

E-mail address: emi_nursanti@uny.ac.id

http://dx.doi.org/10.32601/ejal.911403
} 
the world" (Zein, 2018, p.1), few studies explore this issue, especially among young adult English learners who every day speak their local and national languages.

Aside from being the primary means of communication, language is also often chosen by its speakers to represent their particular individual or group identity (Cleveland, Laroche, \& Papadopoulos, 2015; Joseph, 2004; Kirkpatrick, 2007; Liddicoat \& TaylorLeech, 2014). This means that the language is their 'identity action' indicating which groups they want to be associated with (Block, 2007; Hamers \& Blanc, 2003; Quist, 2005).

Youth, in their transitional age, is often associated with a search of identity and language is one of the ways they choose to form their identity. However, unlike other relatively stable identity markers, like religion, ethnicity, gender, or physical appearance, language is a fluid identity marker (Edwards, 2009) since one can easily play on their language to express or hide certain identities. Therefore, an investigation on identity representation through language is challenging, especially when the speakers are multilingual. Moreover, with the advancement of digital media with English as its dominant language, there must be an identity that develops along with the changing times. The help of various communication modes such as instant messaging and social media allows for significant language changes marked by the emergence of many new vocabularies, genres, and language variations (Warschauer \& Matuchniak, 2010).

Identity-forming is one of the important development goals of the college years (Ortiz \& Santos, 2018), therefore academic learning should involve students' identity formation (Attenborough \& Stokoe, 2012; Kaplan \& Flum, 2012; Tomlinson \& Jackson, 2019). For English language teaching, in Indonesia especially, the tension between developing students' international and national or local identity is inevitably challenging. Moreover, with high global competition and cooperation in this 21st century, the need for knowledge mastery about the world and identity acknowledgment about oneself and others are getting stronger. Efforts to overcome global-local tension are proposed, for instance by UNESCO, emphasizing that "people need gradually to become world citizens without losing their roots and while continuing to play an active part in the life of their nation and their local community" (Delors, 1996, p. 15), To support this, English language instruction in Indonesia should facilitate the learners to be proficient in communicating with the international audience while strongly keep them grounded in their local cultures.

Surrounded by different languages since they are born, Indonesian youth have been accustomed to using different languages in different contexts (Nursanti, Andriyanti, Kurnianta \& Sudartinah, 2020). Considering the Indonesia Constitution No. 24/2009 stating that the Indonesian people should use Bahasa Indonesia (hereafter BI), preserve local languages and learn foreign languages, the youth's exposure to the ambient languages and English they learn as well as the language of technology advancement is worth examining. Proposing an English language instruction approach 
that might suitably be implemented in tertiary education in such context is consequently needed.

\subsection{Language as an expression of identity}

Identity is "meaning of the self-what it means to be who one is" (Burke, 2003, p. 1). It is how someone perceives himself as an individual and as a community member based on the notion of difference or similarity (Furmuzachi, 2007; Riley, 2007), which can be demonstrated through certain symbols, including language, as markers (Chassy, 2015; Drummond, 2018; Riley, 2007) either to other individuals or to other social categories (Turner, Oakes, Haslam \& Mcgarty, 1994).

Language is a flexible and noticeable communicative means of identity expression by which people show who they are and which group they want to be associated with; and therefore it is also an object of such representation from which other people ascribe the speakers' identity (Zenker, 2018). This presumed connection between a person and the language or dialect or sociolect he/she uses (Block, 2007) consists of language expertise, language affiliation, and language inheritance (Leung, Harris \& Rampton cited in Block, 2007). Since people's language inheritance might be different from their language expertise or language affiliation, the classification implies that people might have multiple language identities by which they can play on their language use at a certain time to suit the identity they want to be recognized.

Communication adjustment through verbal or nonverbal behaviors in certain contexts (Gasiorek, 2016) occurs not only in the form of language repertoires but also in several features, such as registers, accents, and speaking speed, accompanied by various paralinguistic features such as smiles and postures (Edwards, 2009; Goebel, 2010; Zenker, 2018). The linguistic strategies applied in communication adjustment enable speakers to pursue positive personal and social identities (Dragojevic, Gasiorek $\&$ Giles, 2016). In relation to group membership, the adjustment people make is sometimes caused by their need that their existence is recognized (Chassy, 2015; Edwards, 2009) and their fear of being excluded if they are unable to actively participate in their networks (Castells, 2001).

The context of language use might change and in the digital era it causes a change in the construct of language users' identity (Blackledge \& Cresse, 2015; Darvin, 2016; Riley, 2007). What used to be a social relationship formed only through meetings and telephone calls has now become intertwined through a variety of facilities provided by increasingly evolving technology. The availability of this technology enables language users to have a variety of identities which can be shown through various modes (Darvin, 2016; Joseph, 2004).

\subsection{Context}

With more than 268 million population spread in 16,056 islands, Indonesia has more than 300 ethnic groups and 1,331 ethnicities (Badan Pusat Statistik, 2020). This 
diversity creates a rich cultural heritage, such as traditions, buildings, clothing, dances, songs, and other cultural products, including languages. Indonesia has 652 local languages, not including the dialect and subdialect (Kemdikbud, 2018). Considering these diverse local cultures as an asset, the government since the country's independence has been committed to maintaining these all as stipulated in the Constitution 1945 Article 32, by "guaranteeing the freedom of the people to maintain and develop cultural values" and "respecting and preserving the languages in the regions as national cultural treasures." Nevertheless, realizing that differences can easily evoke conflicts, a shared national identity is also promoted by establishing a nationally unifying language as stated in Article 36 "The language of the state is Bahasa Indonesia."

Despite the existence of hundreds of local languages and the national language, English becomes a foreign language widely used in Indonesia. Motivated by the need to improve Indonesian political and economic reputation that requires the people to be proficient in a global language (Hamied, 2012), English has been a subject taught in schools and offered in after-school courses.

The perceived significance of English as a modern global language along with the job opportunities it is usually associated with makes more Indonesian youths attracted to study English. Those English adolescent learners tend to use non-standard language and be proud of being a global citizen because of their English mastery (Fitriati \& Wardani, 2020; Rini, 2014; Rohmah, 2005), resulting in the negotiation among identities shaped by their language use.

As multiculturalism and multilingualism are the typical characters of Indonesia, conducting a study in Yogyakarta to get a view on how multilingual Indonesian young adults use their language is plausible since the governor had ever said that Yogyakarta is the miniature of Indonesia (Juningsih, 2015; Winarni, 2018). The city has been widely known as the city of culture and the city of students. Smith-Hefner (2009, p. 57; p. 59) calls Yogyakarta City "a stronghold of traditional Javanese court culture" and "a modern and cosmopolitan education center". The former arouse since it is the only region in Indonesia led by a hereditary governor living in a palace with its good maintenance of old traditions, whereas the latter exists because this small city hosts 138 colleges (Pusdatin Kemenristekdikti, 2018) and the students come from all over Indonesia. "It is a home to dozens of high schools and more than one hundred colleges and universities; ... Young people come to Yogyakarta from across the country seeking an education” ( Smith-Hefner, 2007, pp.187-188).

\section{Method}

\subsection{Participants}

The survey participants of this mixed-methods study were 173 students aged 17 to 23 years old of the English Literature Study Program of a university in Yogyakarta and the ratio of male and female students is around 3: 7. Purposive convenience sampling 
was applied in selecting the interview respondents where their representativeness and availability were taken into account. Table 1 illustrates the students' demography.

Table 1. Place of birth, ethnicity, mother tongue, and place of origin

\begin{tabular}{lrr}
\hline & Frequency & Percentage (\%) \\
\hline Place of birth & & \\
City/regency where the majority of people speak Javanese & 145 & 83.8 \\
City/regency where the majority of people do not speak Javanese & 27 & 15.6 \\
No answer & 1 & 0.6 \\
Ethnicity & 173 & 100.0 \\
Javanese & 129 & 74.6 \\
Javanese father, non-Javanese mother & 12 & 6.9 \\
Javanese mother, non-Javanese father & 21 & 12.1 \\
Non-Javanese & 9 & 5.2 \\
No answer & 2 & 1.2 \\
Mother tongue & 173 & 100.0 \\
Javanese Ngoko (Low/neutral variety of Javanese) & & \\
Javanese Krama (High variety of Javanese) & 91 & 52.6 \\
Bahasa Indonesia & 10 & 5.7 \\
Local language other than Javanese & 68 & 39.3 \\
No answer & 2 & 1.2 \\
& 2 & 1.2 \\
Domicile & 173 & 100.0 \\
An area where most residences speak Javanese & & \\
An area where most residences do not speak Javanese & 143 & 82.7 \\
Other countries & 27 & 15.6 \\
No answer & 1 & 0.6 \\
& 2 & 1.2 \\
\hline
\end{tabular}

\subsection{Instruments}

With an explanatory sequential mixed method design by utilizing qualitative data to explain the quantitative results (Creswell \& Clark, 2018), the instruments employed were justified to yield complementary quantitative and qualitative data. The data consisted of lingual units of students' language in mixed-ethnic interaction both in written and spoken modes, students' responses to the questionnaire, and their responses to the interview questions.

The questionnaire comprises 6 points relating to the criteria intended: 1) demographical situation, 2) language use, 3) language competence, 4) language attitude and perception, 5) local, national, and other group identities, and 6) reasons for choosing a certain language.

Data sheet for observation and interview protocol were used to gain the qualitative data. The data sheet was useful to understand the context in which particular languages are used. A semi-structured interview was conducted with 13 representatives (reported with pseudonyms) to explore six areas on language and identity in general, local language and identity, BI and national identity, English language and identity as students of English Department, language and identity as a youth, and language and millennial generation identity.

\subsection{Piloting and procedures}


The questionnaire employed in this study was mostly adopted from Andriyanti (2016), ensuring the validity and reliability. However, since it was previously used for studying multilingualism in high-school students while the participants in this study were university students, an expert judgement was done for validity and piloting needs conducting to assure that the questionnaire was appropriate. Twenty students of the 2015 enrolment year participated in the pilot project and at the end of the questionnaire were asked to identify if there were problematic items. Based on the feedback given, some changes were made to a small number of items.

After the questionnaire was administered, the collected data were then coded in SPSS 25 for statistical analysis. The audio data gained from the observation and interview were transcribed and utterances related to the issues addressed were highlighted to make it easier for analysis.

\subsection{Analyses}

The quantitative data analysis was carried out using a descriptive statistical method. Meanwhile, qualitative data analysis which is a process of gathering different pieces of interviews and observations into a unified work (Silverman \& Marvasti, 2008) was carried out by condensing the data and displaying them in organized information (Miles, Huberman \& Saldana, 2014).

\section{Results and Discussion}

\subsection{Local identity}

The data gained from the questionnaire depicts that most respondents are Javanese: more than $74 \%$ have both Javanese parents and nearly $60 \%$ use Javanese as the first language. $19 \%$ have mixed-ethnic parents and only about $6 \%$ come from other ethnicities. This illustrates a good transmission rate of Javanese from both parents of Javanese ethnicity to the second generation, which is around 80\%. As mother tongue has a significant role in the formation and continuity of identity (Edwards, 2009; Joseph, 2004), this high level of transmission should be a good signal for maintaining local identities associated with Javanese language and culture.

Table 2. Reasons for using Javanese

\begin{tabular}{|c|c|c|c|c|}
\hline \multirow{2}{*}{$\begin{array}{l}\text { Answer choices (respondent may choose more than } \\
\text { one answer) }\end{array}$} & \multicolumn{2}{|c|}{ Yes } & \multicolumn{2}{|c|}{ No } \\
\hline & Frequency & Percentage (\%) & Frequency & Percentage (\%) \\
\hline Because I am a Javanese & 118 & 68.2 & 55 & 31.8 \\
\hline Proud to be a Javanese & 71 & 41.0 & 102 & 59.0 \\
\hline Want to preserve Javanese language and culture & 94 & 54.3 & 79 & 45.7 \\
\hline Want to show local identity & 75 & 43.4 & 98 & 56.6 \\
\hline $\begin{array}{l}\text { Want to demonstrate the ability in speaking } \\
\text { Javanese }\end{array}$ & 38 & 22.0 & 135 & 78.0 \\
\hline Others want me to speak Javanese & 57 & 32.9 & 116 & 67.1 \\
\hline Comfortable to use & 124 & 71.7 & 49 & 28.3 \\
\hline
\end{tabular}


However, as the statistics reveal rather than conforming to their ethnicity membership or identity, practical reason is the most important when they have to deal with choosing one of the known languages and the most prominent reason for using the local language (Javanese) known from the interview is their comfortable feeling.

Dewi: It's just comfortable to use. Perhaps because it's my mother tongue.

Siska: ... because I feel more comfortable to use Javanese. It's been accustomed since I was a kid.

Budi: Since I am a Javanese, sometimes, when I speak in BI, I feel a bit uneasy.

Dika: As I am more accustomed to speaking in Javanese, if I speak in BI it seems stuffy in an intra-ethnic interaction.

The reason that speaking in their mother tongue is easier and more comfortable should be related to the speakers' competence. For most Javanese youth, their competence in the two ambient languages of Javanese and BI is almost balanced. With regard to Javanese, the Ngoko variety is the speech level that they are more competent at and employed frequently in casual context.

As the speakers' mastery of this variety is over the other languages they know, word chunks in Javanese Ngoko (in bold) sometimes occur in a situation requiring them to use another language.

\section{Sama aku minta maaf aja selama ini dalam ngoprak-ngoprak kalian} ada yang rada ngganjel karena ngoprak-ngoprak terus gitu.

(And I'm sorry for reminding you of your duties over and over. Maybe some of you feel a bit uneasy for always being reminded.)

This excerpt is an utterance spoken in a meeting where the speaker was supposed to speak in BI. Due to her incapability to find words in BI which can represent the same meaning, she took two phrases in Javanese: 'ngoprak-ngoprak' (remind over and over) and 'rada ngganjel' (feel a bit uneasy). Here, the speaker is doing a code mixing.

For multilinguals learning a foreign language, the reasons to mix or switch code are mostly to fulfill their needs and to perform a part of their identity (Abubakr, Hassan \& Muhedeen, 2019), but this current study found the speaker's code mixing is triggered by lexical insufficiency. It may happen to bilinguals fluent in each of the languages they speak (Anastassiou \& Andreou, 2017). Although demonstrating her local identity is not the motive in mixing the code, it is unconsciously demonstrated and is recognized by the listeners.

The respondents' small number of agreement that local language use represents local identity is caused by their disagreement that the only association of local identity is language. For them, identity can also be connected to other aspects, such as arts and ways of life. This claim is partly due to their incapability to speak the high variety of Javanese. Yet, they feel that they still hold the Javanese values and characters. This 
idea can be a justification for students whose one of the parents is Javanese but do not live in Javanese speaking area. For them, their incapacity to speak Javanese fluently should not be a reason to be excluded from the group membership. With a strong exposure to their hometown local language and little knowledge of Javanese vocabulary, the following three respondents do an accommodation process to develop the sense of sameness in their new community.

Aji: Here I sometimes use Javanese even though I rarely use Javanese at home but because now I live in a place where many people use Javanese, the Javanese culture, I adapt to them. I'm still Javanese, anyway.

Heri: Yes. Sometimes I use Javanese. I can, a little. I think it's just better. It is more representative of group identity. That's the nature of a group.

Saras: Javanese but not pure Javanese. To make it acceptable for my friends from Java, since I'm studying here, right? in Jogja.

The students do speech accommodation as an effort to adjust to a particular group to get a group membership (Chassy, 2015; Edwards, 2009). Although using BI is easier and more prestigious for other young people (Arka, 2015; Nurani, 2015; Sitokdana, Tanone, \& Tanaem, 2019), being acknowledged as a group member is more important for these Javanese outsiders.

Meanwhile, the least percentage in Table 2 indicates that not many students employ Javanese to show off and prove that they can speak Javanese. With $82.7 \%$ of them living in Javanese speaking environment, using local language should have been their routine. However, the acknowledgment that they do not use the language to show off is because of their unfamiliarity with Krama (Javanese high variety).

Jaka: No. Because I don't speak their language, so I keep using BI. I never use the local language because I can't.

Maya: I mostly use BI. Yeah, because I can't use the Krama one from childhood.

Different from their perception of the high variety mastery as respected competence, the low variety of Javanese competence is not a capability that should be proud of. Since most young people are not fluent in speaking the Javanese Krama, BI becomes their choice in replacing the Krama.

The respondents' perception that the use of BI is more appropriate than Javanese Ngoko and can mark higher social status becomes the reason why more Javanese young parents, especially those coming from middle- and upper-class families, teach BI to their children as their first language. This conforms to the findings of Smith-Hefner (2009) and Subroto, Dwirahardjo \& Setiawan (2008) that the number of youth using Javanese daily has continuously dropped and over recent decades, the number of BI speakers is on the rise (Cohn \& Ravindranath, 2014) and it is plausible to claim that Javanese, the language with the biggest number of speakers in Indonesia, is at risk of losing the ground (Andriyanti, 2019; Ravindranath \& Cohn, 2014; Vander Klok, 2019). 
The use of speech levels in Javanese makes more youth reluctant to speak the language. However, their limited knowledge of the high variety does not hinder some youths from using this variety since they want to respect the older.

Aji: When I speak to a Javanese older than me, I try to use Javanese as well although it's imperfect.

Wati: If older people speak to me in Javanese then I reply in BI, that's impolite in my family.

Bunga: There are two options when speaking to older people, using Javanese Krama or BI. When we speak in Javanese Krama, it's better. Nowadays, it's more difficult to speak Javanese Krama than BI.

Respecting others is a strong reason for them to keep using Javanese due to the noble value implied in the Javanese culture that younger people should use this variety to the older. This apparently indicates that the society has nurtured the value well.

As Javanese, the participants do not want to lose the Javanese characters. The respecting value contained in Javanese is sometimes performed by the speaker from the words they choose in speaking.

Mas Jovi mangga, waktu dan tempat dipersilakan.

(Mr. Jovi, the floor is yours.)

The excerpt emerged in a semi-formal meeting. The language employed in this meeting was BI but, in this utterance, the speaker unconsciously represents his local identity by using two words 'mas' (an address term for a young man) and 'mangga' (please). Seeing the relationship between the speaker and the addressee, the words in the local language are meant to show respect. However, since they are peers of the same age, the speaker's purpose of employing those words is not for respecting older person. As the hierarchy on who should be respected in Javanese culture is context dependent, the words are intended to respect a person in a higher position than him since in this meeting, the speaker is a master of ceremony and the addressee is a person in charge of an event.

Despite the students' different ethnicities, Javanese is dominating in expressing their local identity. Both in chat group as well as in spoken interaction, students from Javanese actively involved their local language in the conversation. However, this does not create any problems in those mixed-ethnic communities since the words they employed are commonly known by people living in Javanese environment for some time. The respondents also do not have any concern when people relate their local language use with their identity since many decent values are implied in Javanese, like respecting the older and being friendly with the peers.

\subsection{National Identity}


Although national identity includes political aspects, autonomy, and multi-ethnic elements (Ager, 2001; Edwards, 2009; Joseph, 2004), for the respondents in this present study, multi-ethnic elements are the factors triggering them to show their national identity. The choice of using BI that is understood by people of various ethnicities indicates the respondents' awareness to accommodate speech based on shared nationality.

Table 2. Reasons for using BI

\begin{tabular}{|c|c|c|c|c|}
\hline \multirow{2}{*}{$\begin{array}{l}\text { Answer choices (respondent may choose more than } \\
\text { one answer) }\end{array}$} & \multicolumn{2}{|c|}{ Yes } & \multicolumn{2}{|c|}{ No } \\
\hline & Frequency & Percentage (\%) & Frequency & Percentage (\%) \\
\hline Because I am Indonesian & 58 & 33.5 & 115 & 66.5 \\
\hline Want to show nationalism & 36 & 20.8 & 137 & 79.2 \\
\hline Want to demonstrate national identity & 45 & 26.0 & 128 & 74.0 \\
\hline $\mathrm{BI}$ is understood by the majority of Indonesians & 61 & 35.3 & 112 & 64.7 \\
\hline Comfortable to use & 65 & 37.6 & 108 & 62.4 \\
\hline Being tolerant of people from other ethnicities & 54 & 31.2 & 119 & 68.8 \\
\hline
\end{tabular}

The number of students who view the link between BI and national identity is less than $40 \%$ (Table 3), which is different from the link of Javanese. and their local identity. This can be related to the fact that Indonesian people have diverse ethnicities as their constituents. Thus, rather than connecting to their national identity, the national language they choose serves a functional role, which unifies people from different local languages.

The interview reveals the same result that all respondents prefer to use BI as a bridge to communicate with people from different ethnicities. Therefore, conversations involving people from different ethnicities are commonly in BI. However, since the speakers are multilinguals, the BI used by the respondent is sometimes inserted with various numbers of words from English or local language.

[L1] Maaf ya Na salah ngeprint.

(I'm sorry, Na. I printed the wrong file.)

[L2] Ya, prank-e berhasil.

(Yes, the prank was successful.)

[L3] Nah, sebaiknya ada yang, apa jenenge, stand by.

(Better that there is someone who, what is it, stand by.)

The words 'ngeprint' (printed) in L1 and 'prank-e' (the prank) in L2 are words resulted from a combination between English word and Javanese affixes. The utterance in L3 is also a mix of BI, Javanese, and English.

Even when it is used in inter-ethnic communication, mixed code never becomes a serious problem for Indonesians since both the speaker and the listener are multilingual and understand the situation very well. The speakers tend to use vocabulary items easily understood by people of different ethnicities so the listeners will never judge the speakers for being intolerant. Unconsciously, there has been some consideration in both participants regarding the occurrence of code mixing. Thus, for 
Indonesians, although conveyed in a mixed code, the power of $\mathrm{BI}$ as a unifying language is not lessened.

However, in a further investigation, some students claim that they tend to employ BI only to communicate with people they do not know well, and, although the interlocutor is not from the same ethnicity as theirs, they prefer choosing the interlocutor's local language when it is also their known language.

Aji: When I talk to a friend of mine who's from Jakarta, I prefer using language that's commonly used there, like 'lo', 'gue'.

Saras: I can speak Javanese since the majority here are Javanese. But sometimes if I meet my friends from the west, West Java, I mean, I use Sundanese or Betawi language.

The adjustment strategy applied by these respondents is convergence where their communicative behaviors are altered to be more similar to their interlocutor (Dragojevic, Gasiorek \& Giles, 2016). This finding indicates that compared to the national language, the local language is more representative to build intimacy, even with people they do not know well. By utilizing the local language, more personal and pleasant interaction is likely to happen.

Considering that pure BI usage almost never occurs in informal setting among multilingual youths, it is plausible to conclude that their perceived Indonesian identity is not the use of pure and standard BI. A mix of BI, local language, and English, as long as BI is the main language and understood by the interlocutor, is the actualization of their national identity. This should not be regarded as a detriment since mixing code with both local and foreign language elements is a real embodiment of the diversity possessed by the Indonesian people (Nugraha, 2019).

\subsection{Identity as Students of English Department}

Table 4. Reasons for using English

\begin{tabular}{|c|c|c|c|c|}
\hline \multirow{2}{*}{$\begin{array}{l}\text { Answer choices (respondent may choose more than } \\
\text { one answer) }\end{array}$} & \multicolumn{2}{|c|}{ Yes } & \multicolumn{2}{|c|}{ No } \\
\hline & Frequency & Percentage (\%) & Frequency & Percentage (\%) \\
\hline Because I am a student of English Literature & 114 & 65.9 & 59 & 34.1 \\
\hline $\begin{array}{l}\text { Want to show the identity as English Literature } \\
\text { student }\end{array}$ & 45 & 26.0 & 128 & 74.0 \\
\hline Able to speak English & 117 & 67.6 & 56 & 32.4 \\
\hline Want to get used to using English & 156 & 90.2 & 17 & 9.8 \\
\hline Want to show the ability in using English & 62 & 35.8 & 111 & 64.2 \\
\hline Proud of English as a global language & 75 & 43.4 & 98 & 56.6 \\
\hline Want to improve the ability in using English & 158 & 91.3 & 15 & 8.7 \\
\hline
\end{tabular}

Academic purposes are the most prevalent reason for the respondents in employing English. The interview results show that the situation demanding them to demonstrate their identity as English Department students is lectures, speaking in English at the time of presentation, talking with lecturers, or class discussions. However, when they 
are in a classroom, but the lecturer does not require them to use English, some students opt to use BI.

This indicates that the students use English only in study-program-related classes, not in the general courses provided by the faculty or university. In those study-programrelated classes, they feel they are in an English-speaking community even though they are multilingual. Self-identification as a member of the group appears unnoticed.

Some students feel that exposure to using English in the classrooms is insufficient, causing them to take the opportunity to improve their abilities by communicating in English with people close to them when they are in an English-speaking environment. Some of them practice these skills by choosing to join student associations, such as the English Department Students Association (EDSA).

However, although all the members of EDSA are students of English department, they do not use English most of the time due to several factors. One of them is the audiences' language mastery which may affect the information delivery effectiveness. Consequently, in some events held by EDSA, the delivery language is a mix between English and BI.

Our culture is our identity, so be proud of it and uphold it. Pesan terakhir saya adalah semoga kita senantiasa dapat menjadi penjaga gawang kebudayaan kita sendiri.

(My last advice is that we can always be the gatekeepers of our own culture.)

The excerpt is a part of closing in a speech given to new students of English Department. The English part of the speech shows their identity as students of English Department. However, to make the important point delivered well to the audiences, the speaker switches the language into BI considering that the audiences are first semester students who have not yet mastered English well. This language switch implies that identity representation and information delivery sometimes do not work both ways and, in this case, that language is context dependent (Meyerhoff, 2006) is the reason.

With regard to their enrollment in the English Literature study program, the respondents are assumed to have positive attitude toward English. However, with an added value of mastering a foreign language, only $26 \%$ of students like to show this identity in an off-campus environment. Speaking English in an off-campus situation is merely to improve their skills or to make communication more comfortable.

Jaka: I speak English but there is no intention like 'hey I'm an English Literature student'.

Siska: ...because I think I don't need to show that I'm a student of English Literature.

Intan: I speak English when I want to and when I am not able to express myself or when I can't find the right words in BI, so I 
use English. And I never speak English to make people recognize that I am an English Literature student.

Wati: No, since it doesn't need to be shown.

Although they realize that having a good English command is positively valued, society's judgment on people speaking English as a snob is one of the reasons causing them reluctant to show the identity as English department students. The finding that most respondents do not use English in daily communication in off-campus situations is similar to the one found by Lee, Lee, Wong \& Ya'acob (2010) who researched students in Malaysia. There are more students when interviewed said that they did not use English to avoid othering labels from those around them.

Aside from their hiding their English student identity, sometimes the identity arises from others because people see their language habits.

Heri: If we mix in the canteen, then there are students from the Local Language Education or Music majors. So, I'll be indifferent. For example, I wear clothes like this, then I speak English. Then they keep staring at me.

Dika: There is no intention, but sometimes people recognize it. ... When I speak in BI, I frequently code-switch to English, Indonesian-English, Indonesian-English. So, he would know that my major is English.

That their language behavior is an object of which people assign their identity (Zenker, 2018) might not be realized by the students. While most of them admit that their use of English is mostly motivated by academic factors, they unconsciously bring this habit to their daily interaction. Thus, without any intention of showing their identity as English learners, the identity is constructed by others.

\subsection{Youth identity}

While the questionnaire is directed to find the identity representation in relation to their language inheritance and language expertise, the observation and interview found other two types of identity represented by the respondents. The first is identity as young people.

In the interview, the respondents gave varied answers in response to questions about the language they use when communicating in their peer group. Some choose either Javanese, BI, or English and some even employ a mixture of the three in informal forms. The respondents stated that young people are strongly associated with using language that is creative, relaxed, and informal.

Bunga: It's because, you know, youths are more relaxed. They aren't like adults who've been in a certain occupation and with their colleagues speak more formally. 
Budi: Yes, the informal language is like slang and words that don't even exist in KBBI. So that's the identity of young people.

Siska: Yes, because sometimes I slip words that only young people know.

A language that is not strict by rules and whose words are not standard is considered to be more representative of their souls and exclude themselves from the older generation. In Indonesia, an informal speech variety specifically used by youth is known as Bahasa Gaul where most of its lexical items is formed through abbreviation or borrowing (Smith-Hefner, 2007).

[L1] Terus, masih ada miskom pas lagi beresin chamber-chambernya.

(And then, miscommunication still occurred when we're tidying the chambers.)

[L2] QOTD from Mas Eko.

[L3] Kuykuy yg belom sarapan merapat ke c15 ada macaroni goreng . .

(Come on, go to C15 if you haven't got your breakfast. Fried macaroni is available.)

Some lexical items in those extracts are typical words used in Indonesian slang employed by the speakers to demonstrate their identity as youth. The word miskom in L1, a short form of borrowed word 'miscommunication', and QOTD in L2, which stands for 'Quote of the Day', are two examples of abbreviation frequently used in their vernacular along with other popular abbreviations, such as OOTD (outfit of the day), btw (by the way), and otw (on the way). Meanwhile, the word pas (when) in L1 and beresin (tidy up) in L2 are borrowings from local dialects where the former is from Javanese and the latter is Betawi dialect. 'Chamber' in L1 is an English word which is repeated to make it plural as in BI while Kuy in L3 is a common way to create slang words, especially for youth of East Java, by reversing the letter order of the word 'yuk' (come on) into 'kuy'.

That specific language makes the language can be or easily understood by young people only. They employ different vocabulary items and language styles compared to previous generations to mark differences (Chassy, 2015; Preece, 2009). This finding is similar to the comments of several school principals of high schools in Yogyakarta who stated that Indonesian youth's language is strongly influenced by slang and is difficult for older generations to understand (Andriyanti, 2016).

\subsection{Millennial identity}

Besides youth identity, millennial identity is another kind of identity found through observation and interview. The title of millennials or Generation $\mathrm{Z}$ is attached to the respondents because they are considered as a generation with a high level of literacy in the field of communication and information technology and uses various social media to communicate. With the identity closely connected to mobile device technology and 
social media, almost all respondents (172 of 173) use various social media platforms, such as Facebook, Instagram, Twitter, Line, YouTube, Pinterest, and Discord, which allow them to communicate through writing, picture, and or voice.

In the interview, four respondents realize that the language they use online is different from the one they employ when communicating in person.

Aji: Since millennials have their own distinctive styles and discourse to mark that they are from different generations.

Saras: Yes, sometimes I employ slang words, the contemporary language, the millennial language.

In online media, they divide the language into two groups: chatting and making a caption/status. Through interview, it was found that in chatting, many opt to use BI, some prefer Javanese, and a few of them choose English, basically the same language choice in face-to-face interactions. Interestingly, most of them use English to make a caption or status.

Putra: Mostly English, because it's a way cooler.

Wati: But, in caption or status, I use English because English is cooler.

Intan: ...but when I am talking to myself like when I am creating a WhatsApp status, I use English and on Twitter I mostly use English.

With the ability of social media that can be accessed by people from all over the world, there is a tendency for internet users to use English as a global language, on the Internet. Using English in cyberspace which allows them to interact globally can be considered as an 'identity action' (Hamers \& Blanch, 2003; Quist, 2005). They want to show themselves as citizens of cyberspace.

The finding that they employ English more in online social media than in face to face interaction conforms to the idea that changes in the context of communication in the digital age have consequences for changes in identity construct through the use of language (Blackledge \& Cresse, 2015; Darvin, 2016; Riley, 2007). Social media provides a space for them to freely express the identities which are sometimes hindered by their surrounding social custom.

In online social-media interaction, the writing and picture as the main modes do not limit the users' creativity to play on the language to make it as expressive as it is uttered directly in oral conversation. The interactive nature of a chat group makes the language is written to be spoken.

[L1] Tydac

(No)

[L2] Aaaahh tidaaaak mas ekoooo

(Oh no Mr. Eko)

[L3] Hawuu.. love you mas eko. 


\section{[L4] Semangatt teman2 0}

(Keep the spirit, friends)

The excerpts found in students' WhatsApp group are merely some examples that cannot represent how creative the young people nowadays in playing with the language. In [L1], they try to make Indonesian words look like English from the spelling, for example by changing ' $i$ ' into ' $y$ ' and ' $k$ ' into ' $c$ '. Making written language sound as the spoken one is the way applied in [L2] where the student tries to represent her sadness by writing many vocal letters as if she is shouting because someone has just said goodbye. [L3] illustrates youth's creativity by creating spelling based on sound where in that utterance she displays the sound of her crying. Double ' $t$ ' in the word 'semangatt' (keep the spirit) in [L4] as a form of emphasis along with the emoticon of hugging face is an expression of support.

The conclusion that the language of Indonesian youth in peer-group social media is much different from the standard form and structure is similar to the one drawn from some studies in Dutch, Cameroon, and Malaysia claiming that it "deviates" (Verheijen, 2017, p. 79), "bends" (Ojongnkpot, 2017, p. 298), or "does not meet the requirements of" (Hashim, Soopar \& Hamid, 2017, p. 239) the official language writing rules. The hybrid properties of oral and written language (Gee \& Hayes, 2011) in digital media have brought an enormous number of new internet slang which can be a means to form membership and in-group identity (Ojongnkpot, 2017).

\subsection{A local-oriented approach of English instruction}

Referring to the relationship between group membership and cultural identity proposed by Hamers and Blanc (2003), the variety of respondents' group identity does not indicate a multicultural identity. Analogous to the type of that relationship, student respondents have first language monocultural multilinguality signifying that although they master more than one language, their membership and cultural identity still belong to their mother tongue or local culture. Recognition of using language to show identity as Javanese has the largest percentage (68.2\%), followed by recognition related to national identity (33\%), and identity as English Department students (26\%).

Regarding these findings and their major of study, it is essential to maintain their strong attachment to their local and national identity along with the respective cultures and values while mastering the international language. Therefore, a multilingual model of English language teaching (Kirkpatrick, 2011) needs to be applied and a localoriented English instruction might be the most suitable approach. Adapting Kirkpatrick's 'lingua franca approach' (2012) where the curriculum is designed to develop students' intercultural competence and help them communicate by using English in the ASEAN (Association of Southeast Asian Nations) context, this localoriented English is designed to make students able to explore their local cultures to be promoted to the international audiences. 
Based on the motto 'promoting local culture to the international audiences', a balanced content between local culture exploration and international audience understanding should be embodied. This implies that students should learn both local and international cultures. Within this context, the cultures they learn should be seen as a dynamic set of practices that change and evolve constantly rather than as a set of shared information to memorize (Liddicoat, 2002; Thomas Muñoz, 2019). With this perspective in learning language and culture, it is expected that this approach can develop students' capacity to behave and to interact with other people as well as to think and to value critically any cultural phenomenon.

The focus of the instruction is still on developing students' English language mastery, yet the content will not only on the British or American cultures but also the local, national, and regional cultures. In receptive skill courses, as listening and reading, students can be exposed to texts on various topics on ASEAN, Asia, or British, American, and Australian cultures as well as listening to English pronunciation of people from those various countries. While for the productive skill courses which consist of speaking and writing, students can practice presenting a part of their culture or discussing a critical review on that. The theoretical course can also be integrated with such content, like critically analyzing the literary works of authors from ASEAN or Asia, translating local literature, or doing a linguistic analysis of English varieties in non-English speaking countries. By enabling students to engage in such practices, eventually, it will enhance their intercultural competence which involves acceptance and respect to their own culture and other cultures as well as exploring any cultural aspects using their existing information (Liddicoat \& Scarino, 2013).

\section{Conclusions}

With their awareness that language can represent someone's identity, the multilingual students' language choice is mostly governed by practical reason that a certain language can fulfill their needs in a certain context. Nevertheless, either acknowledged by themselves or recognized by others, their everyday language use demonstrates several identities: local identity, national identity, identity as English Department students, youth identity, and millennial identity. By having multiple identities, they have a great ability to adapt to various groups of speakers or language users and adjust the use of language according to the social role they have. Their ability to conduct speech accommodation makes them relatively easy to be accepted in various groups of society. Reflecting on this ability and their strong connection to their local identity, learning English in a local-oriented perspective is necessary to maintain the local cultures and promote them to international audiences.

\section{Acknowledgments}

We thank the Faculty of Languages and Arts of Universitas Negeri Yogyakarta which had provided funding for this research. We also owe Dina Widayanti, Irma Oktaviani, and Nur Chariroh, linguistics students at the English Literature study 
program, for being great assistants in conducting this study, especially during the data collection.

\section{The Research and Publication Ethics Statement}

The Ethics Committee/Board approval for this study was obtained from Institute of Research and Community Service, Universitas Negeri Yogyakarta Ethics Committee in 05/06/2019 No 507-1/UN.34.21/TU/2019. No ethical considerations were violated in this study.

\section{The Conflict of Interest Statement}

In line with the statement of Committee on Publication Ethics (COPE), we hereby declare that we had no conflicting interests regarding any parties of this study. This research study was funded by Fakultas Bahasa dan Seni, Universitas Negeri Yogyakarta (No. 217/UN34.12/PP/2019) without any occurrence of conflicting interest in the manner of author(s).

\section{References}

Abubakr, S. N., Hassan, Z. M., \& Muhedeen, B. L. (2019). Code-switching as identity marker: A sociolinguistic study of Kurdish EFL university students. Journal of University of Human Development, 5(3), 57. https://doi.org/10.21928/juhd.v5n3y2019.pp57-64

Ager, D. (2001). Motivation in language planning and language policy. Clevedon: Multilingual Matters Ltd.

Anastassiou, F., \& Andreou, G. (2017). Factors associated with the code mixing and code switching of multilingual children: An overview. International Journal of Linguistics, Literature and Culture (LLC), 4(3), 2518-3966.

Andriyanti, E. (2016). Multilingualism of high school students in Yogyakarta, Indonesia: The language shift and maintenance. (Unpublished doctoral dissertation). Macquarie University, Sydney, Australia.

Andriyanti, E. (2019). Language shift among Javanese youth and their perception of local and national identities. GEMA Online Journal of Language Studies, 19(3), 109-125. https://doi.org/10.17576/gema-2019-1903-07

Arka, I. W. (2015). Language management and minority language maintenance in ( eastern ) Indonesia : Strategic issues. Language Documentation \& Conservation, 7(2013), 74-105.

Attenborough, F., \& Stokoe, E. (2012). Student life; student identity; student experience: Ethnomethodological methods for pedagogical matters. Psychology Learning \& Teaching, 11(1), 6-21. http://dx.doi.org/10.2304/plat.2012.11.1.6

Badan Pusat Statistik. (2020). Statistik Indonesia-Statistical yearbook of Indonesia 2020. Jakarta: BPS-Statistics Indonesia.

Bhat, M. A. (2017). The changing language roles and linguistic identities of the Kashmiri speech community. Cambridge: Cambridge Scholars Publishing.

Blackledge, A. \& Creese, A. (2015). Emblems of identities in four European urban settings. In J. Nortier \& B.A. Svendsen (Eds.), Language, youth and identity in the $21^{\text {st }}$ century (pp. 167182). Cambridge: Cambridge University Press.

Block, D. (2007). Second language identities. London: Continuum. 
Bristowe, A., Oostendorp, M., \& Anthonissen, C. (2014). Language and youth identity in a multilingual setting: A multimodal repertoire approach. Southern African Linguistics and Applied Language Studies, 32(2), 229-245. https://doi.org/10.2989/16073614.2014.992644

Burke P.J. (2003) Introduction. In P.J. Burke, T.J. Owens, R.T. Serpe, \& P.A. Thoits (Eds.), Advances in identity theory and research (pp. 1-7). Boston, MA: Springer.

Castells, M. (2001). The Internet galaxy: Reflections on the Internet, business and society. Oxford: Oxford University Press.

Chassy, P. (2015). How language shapes social perception. In D. Evans (Ed.), Language and identity: Discourse in the world (pp. 36-51). London: Bloomsbury Academic.

Cleveland, M., Laroche, M., \& Papadopoulos, N., (2015), You are what you speak? Globalization, multilingualism, consumer dispositions and consumption, Journal of Business Research, 68(3), 542-552. https://doi.org/10.1016/j.jbusres.2014.09.008

Cohn, A. C., \& Ravindranath, M. (2014). Local languges in Indonesia: Language maintenance or language shift? Linguistik Indonesia, 32(2), 131-148.

Creswell, J. W., \& Plano Clark, V. L. (2018). Designing and conducting mixed methods research ( $3^{\text {rd }}$ Ed.). Thousand Oaks, California : SAGE.

Darvin, R. (2016). Language and identity in the digital age. In S. Preece (Ed.). The Routledge handbook of language and identity (pp. 523-540). New York: Routledge.

Delors, J. (1996). Learning, the Treasure Within: Report to Unesco of the International Commission on Education for the Twenty-First Century. Paris: Unesco Publishing.

Dragojevic, M., Gasiorek, J., \& Giles, H. (2016). Accommodative strategies as core of the theory. In H. Giles (Ed.), Communication accommodation theory: Negotiating personal relationships and social identities across contexts (pp. 36-59). Cambridge: Cambridge University Press

Drummond, R. (2018). Researching urban youth language and identity. Basingstoke: Palgrave Macmillan.

Edwards, J. (2009). Language and identity: An introduction (Key topics in Sociolinguistics). Cambridge: Cambridge University Press.

Fitriati, A., \& Wardani, M. (2020). Language attitudes and language choice among students in Yogyakarta: A case study at Universitas Sanata Dharma. IJHS (International Journal of Humanity Studies, 3(2), 239-250.

Furmuzachi, G. (2007). Language, identity and multiculturalism. Berlin: Logos Verlag.

Gasiorek, J. (2016). Theoretical perspectives on interpersonal adjustments in language and communication. In H. Giles (Ed.), Communication accommodation theory: Negotiating personal relationships and social identities across contexts (pp. 13-35). https://doi.org/10.1017/CBO9781316226537.002

Gee, J. P., \& Hayes, E. R. (2011). Language and learning in the digital age. New York: Routledge.

Goebel, Z. (2010). Language, migration, and identity: Neighborhood talk in Indonesia. Cambridge: Cambridge University Press.

Hamers, J.F. \& Blanc, M.H.A. (2003). Bilinguality and Bilingualism (2nd Ed.). Cambridge: Cambridge University Press.

Hamied, F. A. (2012). English in multicultural and multilingual Indonesian education. In A. Kirkpatrick \& R. Sussex (Eds.), English as an international language in Asia: Implications for language education (pp. 63-78). London: Springer. https://doi.org/10.1007/978-94-0074578-0

Hashim, F., Soopar, A. A., \& Hamid, A. B. (2017). Linguistic features of Malaysian students' online communicative language in an academic setting: The case of Universiti Kebangsaan Malaysia. Akademika, 87(1), 231-242. https://doi.org/10.17576/akad-2017-8701-17 
Joseph, J. E. (2004). Language and identity: National, ethnic, religious (1 ${ }^{\text {st }}$ Ed.). New York: Palgrave Macmillan.

Juningsih, L. (2015). Multikulturalisme di Yogyakarta dalam perspektif sejarah. Pergulatan Multikulturalisme di Yogyakarta dalam Perspektif Bahasa, Sastra, dan Sejarah. Seminar Dies ke-22 Fakultas Sastra. Yogyakarta: Universitas Sanata Dharma Yogyakarta.

Kaplan, A., \& Flum, H. (2012). Identity formation in educational settings: A critical focus for education in the 21st century. Contemporary Educational Psychology, 37(3), 171-175. https://doi.org/10.1016/j.cedpsych.2012.01.005

Kemdikbud (Kementerian Pendidikan dan Kebudayaan). (2018). Badan Bahasa petakan 652 bahasa daerah di Indonesia. Retrieved from https://www.kemdikbud.go.id/main/blog/2018/07/badan-bahasa-petakan-652-bahasadaerah-di-indonesia

Kirkpatrick, A. (2007). World Englishes: Implications for international communication and English language teaching. Cambridge: Cambridge University Press.

Kirkpatrick, A. (2011). English as an Asian lingua franca and the multilingual model of

ELT. Language Teaching, 44(2), 212-224. doi:10.1017/S0261444810000145

Kirkpatrick, A. (2012). English as an international language in Asia: Implications for language education. Multilingual education, 29-44. https://doi.org/10.1007/978-94-007-4578-0

Lee, S. K., Lee, K. S., Wong, F. F., \& Ya'acob, A. (2010). The English language and its impact on identities of multilingual Malaysian undergraduates. GEMA Online Journal of Language Studies, 10(1), 87-101.

Liddicoat, A.J., (2002). Static and dynamic views of culture and intercultural language acquisition. Babel, 36(3), 4-11.

Liddicoat, A.J., \& Scarino, A. (2013). Intercultural language teaching and learning. West Sussex: Wiley-Blackwell.

Liddicoat, A. J., \& Taylor-Leech, K. (2014). Micro language planning for multilingual education: Agency in local contexts. Current issues in language planning, 15(3), 237-244. https://doi.org/10.1080/14664208.2014.915454

Lie, A. (2017). English and identity in multicultural contexts: Issues, challenges, and $\begin{array}{lcr}\text { opportunities. } & \text { TEFLIN } & \text { Journal. } \\ \text { http://dx.doi.org/10.15639/teflinjournal.v28i1/71-92 }\end{array}$

Meyerhoff, M. (2006). Introducing Sociolinguistics. London \& New York: Routledge.

Miles, M. B., Huberman, A. M., \& Saldana, J. (2014). Qualitative data analysis: A methods sourcebook. Thousand Oaks, California: SAGE.

Nugraha, F. M. (2019). Code mixing as a form of Indonesian identity based on the motto of Bhinneka Tunggal Ika. International Review of Humanities Studies, 4(1), 72-83. https://doi.org/10.7454/irhs.v4i1.108

Nurani, L. M. (2015). Changing language loyalty and identity: An ethnographic inquiry of societal transformation among the Javanese people in Yogyakarta, Indonesia. (Unpublished doctoral dissertation). Arizona State University, Tempe, Arizona, US.

Nursanti, E., Andriyanti, E., Kurnianta, P. \& Sudartinah, T., (2020). Patterns of language use among multilingual university students majoring in English. LITERA, 2(20), 231-244.

Ojongnkpot, C. B. O. (2017). Urban youth language use in social media in Anglophone Cameroon: A morpho-syntactic analysis of Camfranglais among University of Buea students. In A. Ebongue \& E. Hurst (Eds.), Sociolinguistics in African contexts (pp. 287-300). Cham, Switzerland: Springer.

Ortiz, A. M. \& Santoz, S. J. (2010). Campus diversity and ethnic identity development. Diversity \& democracy: Civic learning for shared futures, 13, 5-7. 
Preece, S. (2009). Posh Talk: Language and Identity in Higher Education. Hampshire: Palgrave MacMillan.

Pusdatin Kemenristekdikti. (2018). Higher education statistical year book 2018. Jakarta: Pusat Data dan Informasi Iptek Dikti.

Quist, P. (2005). New Speech varieties among immigrant youth in Copenhagen - a case study. Sprachgrenzen überspringen. Sprachliche Hybridität und polykulturelles Selbstverständnis, 145-161.

Ravindranath, M., \& Cohn, A. C. (2014). Can a language with millions of speakers be endangered? Journal of the Southeast Asian Linguistics Society, 7, 64-75.

Riley, P. (2007). Language, culture and identity. London: Continuum.

Rini, J. (2014). English in Indonesia: Its position among other languages in Indonesia. Beyond Words, 2(2), 19-40.

Rohmah, Z. (2005). English as a global language: Its historical past and its future. Jurnal Bahasa \& Seni, 33(1), 107.

Silverman, D. \& Masvasti, A. (2008). Doing qualitative research: A comprehensive guide. Los Angeles: SAGE Publications.

Sitokdana, M. N. N., Tanone, R., \& Tanaem, P. F. (2019). Digitalization of the local language dictionary of Pegunungan Bintang. Procedia Computer Science, 161, 49-56. https://doi.org/10.1016/j.procs.2019.11.098

Smith-Hefner, N. J. (2007). Youth language, gaul sociability, and the new Indonesian middle class. Journal of Linguistic Anthropology, 17(2), 184-203. https://doi.org/10.4324/9781315675824-19

Smith-Hefner, N. J. (2009). Language shift, gender, and ideologies of modernity in central Java, Indonesia. Journal of Linguistic Anthropology, 19(1), 57-77. https://doi.org/10.1111/j.15481395.2009.01019.x.T

Subroto, D. E., Dwirahardjo, M., \& Setiawan, B. (2008). Endangered Krama and Krama Inggil varieties of the Javanese language. Linguistik Indonesia, 26(1), 89-96.

Thomas Muñoz, R. (2019). Promote local culture and products. In L. F. Walter (Ed.) Encyclopedia of the UN Sustainable Development Goals (pp. 1-9). Cham, Switzerland: Springer.

Tomlinson, M. \& Jackson, D. (2021) Professional identity formation in contemporary higher education students. Studies in Higher Education, 46(4), 885-900. doi:10.1080/03075079.2019.1659763.

Turner, J. C., Oakes, P. J., Haslam, S. A., \& Mcgarty, C. (1994). Personal and social identity: self and social context. Personality and Social Psychology Bulletin, 20(5), 454-463.

Vander Klok, J. (2019). The Javanese language at risk? Perspectives from an East Java village. Language Documentation \& Conservation, 13, 300-345.

Verheijen, L. (2017). WhatsApp with social media slang?: Youth language use in Dutch written computer-mediated communication. In D. Fišer \& M. Beißwenger (Eds.), Investigating computer-mediated communication: Corpus-based approaches to language in the digital world (pp. 72-101). Ljubljana: Znanstvena založba Filozofske fakultete UL.

Warschauer, M. \& Matuchniak, T. (2010). New technology and digital words: Analyzing evidence of equity in access, use, and outcomes. Review of research in education, 34(1), 179-225.

Winarni, F. (2018). Aspek hukum peran serta masyarakat dalam pelestarian cagar budaya. Mimbar Hukum - Fakultas Hukum Universitas Gadjah Mada, 30(1), 96-108. https://doi.org/10.22146/jmh.29160

Zentz, L. (2012). Global language identities and ideologies in an Indonesian university context. Unpublished doctoral dissertation. University of Arizona, Tucson, Arizona. 
Zein, S. (2018). English, multilingualism and globalisation in Indonesia. English Today, 1-6. doi:10.1017/s026607841800010x

Zenker, O. (2018). Language and identity. In H. Callan (Ed.), The international encyclopedia of Antrhropology (pp. 1-7). Oxford: Wiley Blackwell.

\section{Copyrights}

Copyright for this article is retained by the author(s), with first publication rights granted to the Journal. This is an open-access article distributed under the terms and conditions of the Creative Commons Attribution license (CC BY-NC-ND) (http://creativecommons.org/licenses/by-nc-nd/4.0/). 